\title{
Intravenous immunoglobulin as clinical immune-modulating therapy
}

\author{
Laurent Gilardin MD, Jagadeesh Bayry DVM PhD, Srini V. Kaveri DVM PhD
}

I ntravenous immunoglobulin is derived from pooled plasma from thousands of healthy donors and contains polyspecific IgG. In addition to its indication for immunodeficiency disorders, immunoglobulin is used in a variety of immune-mediated disorders. Several issues remain unresolved: optimal dose, differences in composition between products, and combination therapy with other biologics. More importantly, the mechanisms of action of immunoglobulin remain elusive, although several mutually nonexclusive effects have been proposed. ${ }^{1}$

In this article, we summarize the impact of intravenous immunoglobulin on the immune system. We also discuss clinical use, emphasizing the evidence supporting immunoglobulin's use as an immune-modulating agent. Depending on the disease, there is huge variability in the quality of evidence, from single case reports to well-conducted randomized controlled trials (RCTs). The search strategy used for this review is presented in Box 1.

\section{What is the immunologic basis for intravenous immunoglobulin use?}

Autoimmune and inflammatory diseases are associated with a highly perturbed immune system implicating various immune cells and inflammatory mediators such as cytokines and chemokines. It is therefore unlikely that a single component of intravenous immunoglobulin provides the immunologic basis for its use as an immune-modulating agent. Depending on the disease and models, different mechanisms of action have been identified, although it is possible that these mechanisms work in a synergistic manner (Figure 1).

One of the first identified mechanisms of action of intravenous immunoglobulin was blockade of Fc $\gamma$ receptors on macrophages, thereby inhibiting platelet phagocytosis in idiopathic thrombocytopenic purpura. ${ }^{2}$ Subsequently, immunoglobulin was shown to exert an anti-inflammatory effect through upregulation of inhibitory Fc $\gamma$ receptor IIB on macrophages. ${ }^{3} \mathrm{Fc} \gamma$ receptor IIB contains an immunoreceptor tyrosine-based inhibitory motif that switches off the intracellular inflammatory cascade. Intravenous immunoglobulin inhibits complement-mediated tissue damage and modulates the cytokine network: it suppresses the production of proinflammatory cytokines ${ }^{4}$ while increasing the production of anti-inflammatory mediators such as interleukin-1 receptor antagonist.

Intravenous immunoglobulin modulates different cells of the innate and adaptive immune compartments, including dendritic cells, monocytes and macrophages, granulocytes, natural killer cells, B cells and various subsets of T cells. ${ }^{5}$ It expands the number of regulatory $\mathrm{T}$ cells, which play a critical role in maintaining immune tolerance, ${ }^{6}$ and inhibits the differentiation and function of $\mathrm{T}$ helper 17 and $\mathrm{T}$ helper 1 cells, ${ }^{7}$ which are involved in several autoimmune diseases. Intravenous immunoglobulin alters Band T-cell interactions and downregulates pathogenic antibody production. ${ }^{8}$

\section{For which diseases is intravenous immunoglobulin effective?}

Autoimmune diseases are rare and heterogeneous, involve complex and different physiopathologic mechanisms and demand multiple treatment strategies with varying outcomes. Determining the efficacy of intravenous immunoglobulin for these conditions requires selection of clinically relevant outcome measures that are assessed at appropriate points. Although a limited number of placebo-
Competing interests: None declared.

This article has been peer reviewed.

Correspondence to: Srini Kaveri, srini.kaveri @crc.jussieu.fr

CMAJ 2015. DOI:10.1503 /cmaj.130375

\section{KEY POINTS}

- Intravenous immunoglobulin exerts anti-inflammatory and immunemodulating effects through broad and possibly synergistic mechanisms.

- Conditions for which clear evidence favours first-line use of intravenous immunoglobulin include idiopathic thrombocytopenic purpura, Kawasaki disease and polyneuropathies such as Guillain-Barré syndrome.

- Most unlicensed and off-label use is supported by little or no evidence.

- Prioritization of indications for this limited and costly product is important to avoid the risk of shortages owing to increasing off-label use. 
controlled trials have shown its efficacy, intravenous immunoglobulin is helpful and may avoid the excessive use of immunosuppressive agents such as corticosteroids or invasive procedures such as plasmapheresis. Use of intravenous immunoglobulin is established as a first-line treatment in patients with the following indications.

\section{Neurologic disorders}

Intravenous immunoglobulin is effective in the treatment of peripheral nervous system disorders. ${ }^{9,10}$

In chronic inflammatory demyelinating polyneuropathy, evidence for the use of immunoglobulin $(2 \mathrm{~g} / \mathrm{kg})$ is supported by a meta-analysis of seven RCTs involving 287 patients. ${ }^{11}$ Compared with placebo, immunoglobulin resulted in significantly higher rates of improvement overall (44\%, 95\% confidence interval [CI] $32 \%$ to $62 \%$, v. $18 \%$ ) and reduction in degree of disability (relative risk [RR] 2.4, 95\% CI 1.72 to 3.36 ) over study durations of two to six weeks. The short-term efficacy of intravenous immunoglobulin is similar to that of plasma exchange and corticosteroid therapy but with a better tolerance profile. ${ }^{12}$ The benefit of immunoglobulin is transient, however, and long-term management of the disease may require regular infusions.

Intravenous immunoglobulin is used in addition to supportive care in patients with GuillainBarré syndrome and should be started within two weeks from disease onset according to expert opinion. A Cochrane systematic review ${ }^{13}$ showed that, in at least three RCTs enrolling up to 536 patients, daily doses of $0.4 \mathrm{~g} / \mathrm{kg}$ for five days improved motor function at one month and reduced time to recovery, efficacy similar to that seen with plasmapheresis. However, intravenous immunoglobulin did not significantly change the disability grade (mean difference -0.02 of a grade, $95 \% \mathrm{CI}-0.25$ to 0.2 ).

In myasthenia gravis, the indication for intravenous immunoglobulin is restricted to either

\section{Box 1: Evidence used in this review}

We used national guidelines from France, the United States, the United Kingdom, Canada and Australia to identify approved indications for intravenous immunoglobulin in autoimmune and inflammatory diseases (Appendix 1). In addition, we searched MEDLINE (1980 to present) and the Cochrane Database of Systematic Reviews using the following terms: "immunoglobulins, intravenous," "immunoglobulins," "IVIg" and the relevant diseases mentioned in the national guidelines. We excluded the diseases for which there was insufficient evidence and restricted our review to the literature published in English or French. Additional articles were identified through manual searches of the reference lists of relevant articles. We used the US Department of Health and Human Services' Agency for Healthcare Research and Quality system to assess the level of evidence (see details in Appendix 2). [Appendices are available at www.cmaj.ca/lookup /suppl/doi:10.1503/cmaj.130375/-/DC1] exacerbated or worsened clinical conditions, because first-line treatment with oral cholinesterase inhibitors is sufficient in most patients. ${ }^{14} \mathrm{Lim}-$ ited evidence from a subgroup of 28 patients with severe disease in an RCT of immunoglobulin ( $2 \mathrm{~g} / \mathrm{kg}$ ) versus placebo showed clinically important improvement after 14 days in the quantified myasthenia gravis score, a validated measure of target organ function (mean difference -3.40 , $95 \%$ CI -5.74 to -1.06 ). In another RCT, involving 84 patients, intravenous immunoglobulin showed an improvement rate similar to that seen after five sessions of plasmapheresis $(69 \% \mathrm{v}$. $65 \%, p=0.74) .{ }^{15}$ A lower dose of $1 \mathrm{~g} / \mathrm{kg}$ may be sufficient, because it showed similar efficacy to a dose of $2 \mathrm{~g} / \mathrm{kg}$ in an RCT involving 168 patients. ${ }^{16}$ In Guillain-Barré syndrome and myasthenia gravis, the choice between intravenous immunoglobulin and plasmapheresis should be based on the practical availability and respective contraindications related to each therapy.

High-dose immunoglobin treatment (2 to $2.5 \mathrm{~g} / \mathrm{kg}$ ) is indicated for use in multifocal motor neuropathy, based on a meta-analysis of four RCTs involving 34 patients. ${ }^{17}$ Compared with placebo, immunoglobulin showed greater (albeit nonsignificant) reductions in disability (39\% v. $11 \%$; RR 3, 95\% CI 0.89 to 10.12 ) and significantly higher rates of improvement in muscle strength (78\% v. 4\%; RR $11.00,95 \%$ CI 2.86 to 42.25 ). Intravenous immunoglobulin should be considered as first-line therapy in view of the lack of alternative treatments with an acceptable safety profile. However, cost-benefit issues should be considered, because maintenance therapy is often required.

\section{Autoimmune mucocutaneous blistering diseases}

Intravenous immunoglobulin may be effective in corticosteroid-resistant pemphigus vulgaris or pemphigus foliaceus. ${ }^{18}$ Only one RCT, involving 61 patients, compared a single cycle of immunoglobulin ( 0.4 or $0.2 \mathrm{~g} / \mathrm{kg}$ daily for five days) with placebo. ${ }^{19}$ Patients who received $0.4 \mathrm{~g} / \mathrm{kg}$ of immunoglobulin stayed on the protocol significantly longer than those given placebo $(p<0.001)$ without the need for additional treatment during an 85-day observation period. The most effective way of using immunoglobulin in pemphigus has not yet been determined, and response rates appear higher when the agent is given in combination with other biologics than when given alone (91\% v. 56\%). ${ }^{20}$ In particular, combination therapy with rituximab seems promising.

In bullous pemphigoid, weak evidence suggests that intravenous immunoglobulin could be used as adjuvant therapy to corticosteroids in refractory 
cases or as a sparing agent to prevent adverse effects of immunosuppressive drugs. A recent review of 41 published case reports showed that a cycle of immunoglobulin of $2 \mathrm{~g} / \mathrm{kg}$ was clinically effective in about $80 \%$ of the patients and led to the withdrawal of other immunosuppressive treatment. ${ }^{21}$ In view of the limitations owing to diverse definitions for outcome measures, ${ }^{22}$ it is difficult to compare the efficacy of therapeutic alternatives and to indicate a schedule of treatment.

\section{Idiopathic thrombocytopenic purpura}

The efficacy of intravenous immunoglobulin on the recovery of platelets in idiopathic thrombo- cytopenic purpura has long been shown to be similar to that of steroids, with some advantages. ${ }^{23}$ Several dosage regimens of immunoglobulin have been designed, and in a metaanalysis of 13 trials enrolling 646 patients, ${ }^{24}$ a dose of $1 \mathrm{~g} / \mathrm{kg}$ for two consecutive days had an efficacy rate of about $80 \%$ in obtaining an increase of more than 50000 platelets per $\mathrm{mm}^{3}$ $\left(50 \times 10^{9} / \mathrm{L}\right)$ on day 5 . In relapsing idiopathic thrombocytopenic purpura, repeat infusion of immunoglobulin could constitute an alternative for splenectomy, ${ }^{25}$ although newer strategies such as rituximab and thrombopoietin receptor agonists are currently favoured.

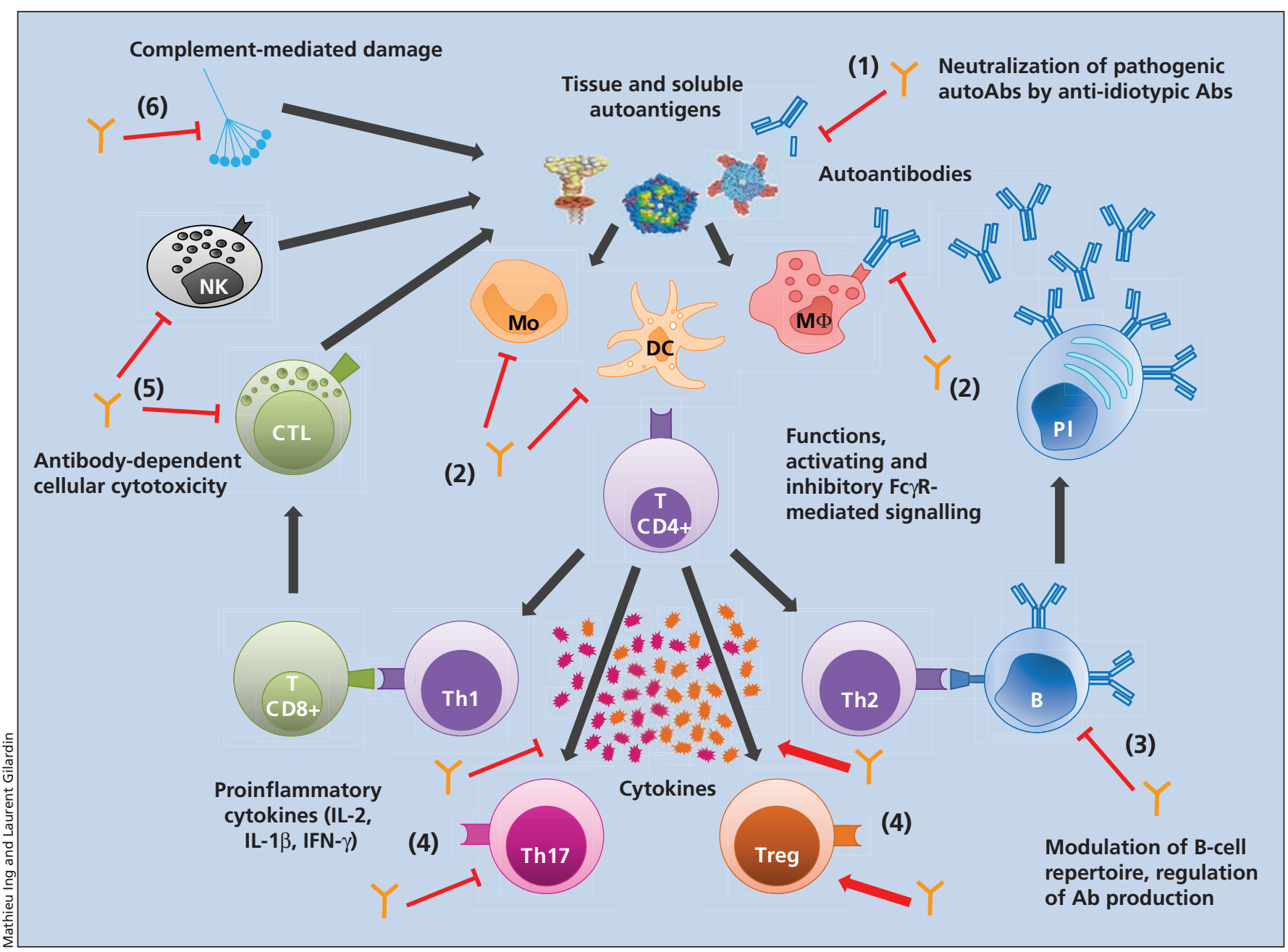

Figure 1: Impact of intravenous immunoglobulin on the immune system. Exposure of autoantigens triggers the recognition by antigenpresenting cells, leading to activation and polarization of $\mathrm{T}$ helper cells. $\mathrm{T}$ helper cells and innate cells provide activation signals through cytokines, which leads either to production of autoantibodies from the differentiated B cells into plasma cells or to tissue damage from the release of inflammatory mediators by immune cells, complement activation and antibody-dependent cell-mediated cytotoxicity. Intravenous immunoglobulin interacts with various cellular and soluble components of the immune system involved in the inflammatory and autoimmune process: (1) it neutralizes pathogenic autoantibodies through the anti-idiotypic network; (2) it modulates the expression of Fc receptors and inhibits the maturation and activation of antigen-presenting cells; (3) it regulates antibody synthesis and the B-cell repertoire; (4) it shifts the balance between subsets of T helper cells and downregulates the production of proinflammatory cytokines by T cells; (5) it blocks antibody-dependent cell-mediated cytotoxicity; and (6) it blocks complement activation. Orange antibody structures = intravenous immunoglobulin; dark grey arrows = activation signalling; red arrows = agonist effect of intravenous immunoglobulin; red $\mathrm{T}$ bars $=$ inhibitory effect of intravenous immunoglobulin. $\mathrm{Ab}=\mathrm{antibody}, \mathrm{B}=\mathrm{B}$ cell, $\mathrm{CTL}=\mathrm{cytotoxic}$ T cell, $\mathrm{DC}=$ dendritic cell, $\mathrm{Fc} \gamma \mathrm{R}=\mathrm{Fc} \gamma$ receptor, IFN = interferon, IL = interleukin, Mo = monocyte, $\mathrm{M} \Phi=\mathrm{macrophage}, \mathrm{NK}=\mathrm{natural}$ killer cell, $\mathrm{PI}=$ plasma cell, $\mathrm{Th}=\mathrm{T}$ helper cell, Treg $=$ regulatory $\mathrm{T}$ cell. 


\section{Kawasaki disease}

Beneficial effects of intravenous immunoglobulin have been clearly shown in patients with Kawasaki disease. ${ }^{26}$ In one trial, involving 85 children, high doses of immunoglobulin $(0.4 \mathrm{~g} / \mathrm{kg}$ daily for four days) reduced the occurrence of coronary artery abnormalities at day 30 compared with acetylsalicylic acid (ASA) alone (15\% v. $42 \%, p=$ 0.006). ${ }^{27} \mathrm{~A}$ meta-analysis of several studies, involving more than 1000 children, showed that immunoglobulin given at a high infusion rate $(2 \mathrm{~g} / \mathrm{kg}$ over $10 \mathrm{~h})$ and in combination with ASA and steroids reduced the rate of coronary artery defects significantly more than a standard immunoglobulin regimen combined with ASA (7.6\% v. $18.9 \%$; odds ratio $0.3,95 \% \mathrm{CI} 0.20$ to 0.46$){ }^{28}$

\section{Kidney transplantation}

Few treatment options are available to enable patients highly sensitized to human leukocyte antigens (HLA) to undergo kidney transplantation. An RCT involving 24 patients showed that, compared with placebo, intravenous immunoglobulin at a dose of $2 \mathrm{~g} / \mathrm{kg}$ monthly for four months before transplantation significantly reduced anti-HLA antibody levels and the projected mean time to transplantation $(4.8$ v. $10.3 \mathrm{yr}, p<0.05) .{ }^{29}$ Another $\mathrm{RCT}$, involving 30 patients with steroid-resistant graft rejection, showed that intravenous immunoglobulin at $0.5 \mathrm{~g} / \mathrm{kg}$ daily for seven days provided a two-year graft survival rate of $80 \%$, similar to that achieved with muromonab-CD3. ${ }^{30}$

\section{Inflammatory myopathy}

Intravenous immunoglobulin has been used successfully in steroid-resistant and severe forms of myopathy. ${ }^{31,32}$ In dermatomyositis, a pivotal RCT of three monthly injections of immunoglobulin $(2 \mathrm{~g} / \mathrm{kg})$ versus placebo in 15 patients showed a rapid and significant improvement $(p<$ 0.02 ) in the mean muscle strength score in the treatment group (from $76.6 \pm 5.7$ standard deviations to $84.6 \pm 4.6$ ), compared with no change in the placebo group (from $78.6 \pm 6.3$ to $78.6 \pm$ 8.2). In polymyositis, no randomized studies were identified in the literature search, but intravenous immunoglobulin was found to be effective in uncontrolled studies. . $^{33,34}$

\section{Other diseases}

Evidence, albeit relatively weak, has shown promising outcomes with the use of intravenous immunoglobulin in several other conditions. For some of these indications, use of immunoglobulin is authorized by national drug agencies; for others, it is off-label use. The lack of evidence is due mainly to underpowered studies related to small numbers of patients. Systematic reviews and guidelines ${ }^{35,36}$ specify the level of evidence, the details of which are summarized in Table 1 .

\section{For which diseases is intravenous immunoglobulin not recommended?}

In certain diseases, the use of intravenous immunoglobulin has met with only little efficacy and is therefore not recommended. In others, it is not recommended based on a strong level of evidence (RCTs or meta-analyses of RCTs). For example, in relapsing-remitting multiple sclerosis, an RCT involving 150 patients showed no improvement in the occurrence of relapses with immunoglobulin versus placebo. ${ }^{37}$ Immunoglobulin was found to be ineffective in secondary progressive multiple sclerosis in a placebocontrolled RCT involving 197 patients. ${ }^{38}$ A recent placebo-controlled RCT failed to show a beneficial effect in Alzheimer disease. ${ }^{39}$ In juvenile rheumatoid arthritis, inclusion body myositis and eczema, evidence from small RCTs failed to support immunoglobulin use. ${ }^{40-42}$

In other diseases, alternative treatments are more effective. In an observational study involving infants with autoimmune neutropenia, 50\% of those given intravenous immunoglobulin before elective surgery or because of severe infection responded to treatment, as compared with $100 \%$ of the eight patients given granulocyte colony-stimulating factor. ${ }^{43}$ In chronic fatigue syndrome, asthma and schizophrenia, the efficacy of immunoglobulin seems to be unlikely because the physiologic rationale is not sound.

In certain conditions, intravenous immunoglobulin has been shown to be deleterious and should be avoided. A trial of immunoglobulin therapy for the DRESS (drug reaction with eosinophilia and systemic symptoms) syndrome was stopped because of serious adverse events (severe malaise with hemodynamic changes during immunoglobulin infusion, and pulmonary embolism and hemophagocytic syndrome during follow-up)..$^{44}$ Although use of immunoglobulin as first-line treatment in diseases such as hemophagocytic syndrome has been reported in a few cases, ${ }^{45}$ another report ${ }^{46}$ suggests that it is not adequate for secondary hemophagocytic syndrome related to Epstein-Barr virus infection and would delay the appropriate treatment.

\section{What are the adverse effects?}

The most common adverse events associated with intravenous immunoglobulin use are mild and transient (Table 2) ${ }^{47}$ Potentially serious but 
Table 1: Autoimmune and inflammatory diseases* with limited evidence for intravenous immunoglobulin use ${ }^{2,3}$

\begin{tabular}{|c|c|c|c|}
\hline Disease & Context & Outcome expected & $\begin{array}{l}\text { Level of } \\
\text { evidencet }\end{array}$ \\
\hline Stiff-person syndrome & $\begin{array}{l}\text { - Presence of anti-glutamic acid decarboxylase } \\
\text { antibodies } \\
\text { - Second- or third-line treatment }\end{array}$ & $\begin{array}{l}\text { - Reduction in stiffness, in number of } \\
\text { spasms (score) } \\
\text { - Improvement in 10-m up-and-go walk test }\end{array}$ & $1 b \neq$ \\
\hline $\begin{array}{l}\text { ANCA-associated vasculitis } \\
\text { and central nervous system } \\
\text { vasculitis }\end{array}$ & $\begin{array}{l}\text { - Persistent disease activity or relapse in patient } \\
\text { previously treated with immunosuppressive } \\
\text { drugs }\end{array}$ & - Short-term reduction in disease activity & $1 b \S$ \\
\hline $\begin{array}{l}\text { Acquired von Willebrand } \\
\text { syndrome }\end{array}$ & $\begin{array}{l}\text { - Life- or limb-threatening bleeding } \\
\text { - Prior invasive procedures } \\
\text { - Combination with steroids or other } \\
\text { immunosuppressive drugs } \\
\text { - Second- or third-line treatment }\end{array}$ & $\begin{array}{l}\text { - Cessation of bleeding } \\
\text { - Sustained or longer response }\end{array}$ & $2 a$ \\
\hline $\begin{array}{l}\text { Toxic epidermal necrolysis } \\
\text { and Stevens-Johnson } \\
\text { syndrome }\end{array}$ & $\begin{array}{l}\text { - Severe form (life threatening) } \\
\text { - Contraindication to other immunosuppressive } \\
\text { drugs } \\
\text { - Combination with steroids }\end{array}$ & $\begin{array}{l}\text { - Resolution of disease } \\
\text { - Reduction in mortality and in severity } \\
\text { score }\end{array}$ & $2 a$ \\
\hline Rasmussen syndrome & - Second- or third-line treatment & $\begin{array}{l}\text { - Reduction in frequency of seizures } \\
\text { - Improvement in cognitive state }\end{array}$ & $2 b$ \\
\hline Severe $\mathrm{Rh}$ hemolytic disease & $\begin{array}{l}\text { - Aggravation despite phototherapy } \\
\text { - Combination with other treatments }\end{array}$ & $\begin{array}{l}\text { - Resolution of hyperbiliburinemia } \\
\text { - Reduction in need for exchange } \\
\text { transfusion }\end{array}$ & 3 \\
\hline $\begin{array}{l}\text { Erythroblastopenia due to } \\
\text { human parvovirus B19 } \\
\text { infection }\end{array}$ & $\begin{array}{l}\text { - Relapse and third-line treatment (failure of } \\
\text { steroids and other immunosuppressive drugs) }\end{array}$ & - Correction of anemia & 3 \\
\hline $\begin{array}{l}\text { Autoimmune uveitis and } \\
\text { birdshot chorioretinopathy }\end{array}$ & $\begin{array}{l}\text { - Sight threatening } \\
\text { - Flare-up or requirement of high dose of } \\
\text { steroids }\end{array}$ & $\begin{array}{l}\text { - Increase in visual acuity } \\
\text { - Reduction in macular edema } \\
\text { - Reduction in dose of steroids }\end{array}$ & 3 \\
\hline $\begin{array}{l}\text { Autoimmune hemolytic } \\
\text { anemia }\end{array}$ & $\begin{array}{l}\text { - Positive result of antiglobulin test (IgG) } \\
\text { - Second- or third-line treatment (failure of } \\
\text { steroids and other immunosuppressive drugs or } \\
\text { contraindications) } \\
\text { - Combination with other treatments }\end{array}$ & - Correction of anemia & 3 \\
\hline $\begin{array}{l}\text { Streptococcal or } \\
\text { staphylococcal sepsis and } \\
\text { toxic shock syndrome }\end{array}$ & $\begin{array}{l}\text { - Infection refractory to aggressive therapy, } \\
\text { with persistent organ failure } \\
\text { - Life-threatening infection } \\
\text { - Combination with other treatments }\end{array}$ & $\begin{array}{l}\text { - Improvement in survival } \\
\text { - Reduction in length of hospital stay }\end{array}$ & 3 \\
\hline $\begin{array}{l}\text { Alloimmune } \\
\text { thrombocytopenia (fetal or } \\
\text { neonatal) }\end{array}$ & $\begin{array}{l}\text { - Fetal: first-line treatment in pregnant women } \\
\text { with history of neonatal alloimmune } \\
\text { thrombocytopenia } \\
\text { - Neonatal: failure of platelet-rich plasma } \\
\text { therapy, or not available or advisable }\end{array}$ & $\begin{array}{l}\text { - Increase in live-birth rate } \\
\text { - Rise in platelet count }\end{array}$ & 3 \\
\hline Systemic lupus erythematosus & $\begin{array}{l}\text { - Severe cytopenias } \\
\text { - Combination with other treatments }\end{array}$ & - Correction of cytopenias & 3 \\
\hline $\begin{array}{l}\text { Autoimmune congenital } \\
\text { heart block }\end{array}$ & $\begin{array}{l}\text { - Presence of anti-Ro or anti-La antibodies in } \\
\text { pregnant women with history of heart block }\end{array}$ & $\begin{array}{l}\text { - Improvement in degree of heart block at } \\
\text { birth }\end{array}$ & 3 \\
\hline $\begin{array}{l}\text { Systemic onset juvenile } \\
\text { idiopathic arthritis (Still } \\
\text { disease) }\end{array}$ & $\begin{array}{l}\text { - Severe disease with prominent cutaneous } \\
\text { involvement } \\
\text { - Failure of steroids and other } \\
\text { immunosuppressive drugs } \\
\text { - Combination with other treatments }\end{array}$ & $\begin{array}{l}\text { - Reduction in systemic symptoms } \\
\text { - Reduction in dose of steroids }\end{array}$ & 3 \\
\hline $\begin{array}{l}\text { Catastrophic antiphospholipid } \\
\text { syndrome }\end{array}$ & $\begin{array}{l}\text { - Combination with anticoagulation and } \\
\text { supportive therapy } \\
\text { - Plasmapheresis not available }\end{array}$ & - Improvement in survival & 3 \\
\hline $\begin{array}{l}\text { Secondary hemophagocytic } \\
\text { syndrome }\end{array}$ & $\begin{array}{l}\text { - Associated with viral infection, cancer, } \\
\text { lymphoma or lupus }\end{array}$ & $\begin{array}{l}\text { - Improvement in survival } \\
\text { - Correction of pancytopenia }\end{array}$ & 3 \\
\hline \multicolumn{4}{|c|}{$\begin{array}{l}\text { Note: ANCA = antineutrophil cytoplasmic antibodies, RCT = randomized controlled trial. } \\
\text { *Indications for use of intravenous immunoglobulin as first-line treatment are discussed in the text. } \\
\text { tWe used the US Department of Health and Human Services' Agency for Healthcare Policy and Research system to assess the level of evidence (see details in } \\
\text { Appendix 2, available at www.cmaj.ca/lookup/suppl/doi:10.1503/cmaj.130375/-/DC1). } \\
\text { fRCT involving } 16 \text { patients. } \\
\text { §RCT involving } 34 \text { patients. }\end{array}$} \\
\hline
\end{tabular}


less common events include volume overload, acute renal failure, thromboembolism and anaphylaxis. Adverse reactions are generally managed with supportive treatment and by slowing or stopping the immunoglobulin infusion.

Contamination of immunoglobulin with infectious agents is always a possibility. However, multiple steps of chemical and enzymatic purification followed by chemical or physical virus inactivation help improve the safety of the product. ${ }^{48}$

\section{Unanswered questions}

Although intravenous immunoglobulin has been widely used as an immune-modulating agent for more than 30 years, little is known about factors

Table 2: Adverse effects associated with intravenous immunoglobulin use

\begin{tabular}{|c|c|c|c|c|c|}
\hline Adverse event & $\begin{array}{l}\text { Frequency, } \\
\%\end{array}$ & Risk factors & Mechanism of action & $\begin{array}{l}\text { Preventive strategies } \\
\text { and treatment }\end{array}$ & Severity \\
\hline $\begin{array}{l}\text { Flu-like syndrome: } \\
\text { flushing, headache, chills, } \\
\text { low-grade fever, nausea, } \\
\text { malaise, mild } \\
\text { hypotension, muscle } \\
\text { aches during infusion }\end{array}$ & $1-15$ & $\begin{array}{l}\text { - Fast infusion rate } \\
\text { - IgA proportion } \\
\text { - First infusion of IVIg }\end{array}$ & $\begin{array}{l}\text { - Fc receptor-mediated release } \\
\text { of prostaglandins, platelet- } \\
\text { activating factor and } \\
\text { cytokines from leukocytes } \\
\text { - Aggregation of lgG, leading } \\
\text { to complement activation } \\
\text { - Formation of immune } \\
\text { complex }\end{array}$ & $\begin{array}{l}\text { - Slow infusion rate } \\
\text { - Discontinuation of infusion } \\
\text { - Product brand substitution } \\
\text { - Premedication with one or } \\
\text { more of antipyretic, } \\
\text { corticosteroid or antihistamine } \\
\text { - Subcutaneous infusion }\end{array}$ & $\begin{array}{l}\text { Mild and } \\
\text { transient }\end{array}$ \\
\hline $\begin{array}{l}\text { Intravascular acute } \\
\text { hemolysis during infusion } \\
\text { and lasting up to } 3 \mathrm{~d} \\
\text { after infusion }\end{array}$ & $<0.1$ & $\begin{array}{l}\text { - High-dose infusion } \\
\text { - Blood group other than } \\
\text { type O } \\
\text { - Multiparous women } \\
\text { - Higher titers of anti-A or } \\
\text { anti-B IgG antibodies }\end{array}$ & $\begin{array}{l}\text { - Passive transfer of antibodies } \\
\text { (isohemagglutinins) against } \\
\text { antigens of ABO and Rh } \\
\text { - Underlying inflammatory } \\
\text { state }\end{array}$ & $\begin{array}{l}\text { - Blood type cross-matching } \\
\text { - Determination of anti-A and } \\
\text { anti-B antibody titer before } \\
\text { infusion } \\
\text { - Post-transfusion testing for } \\
\text { hemolysis within } 36 \mathrm{~h} \text { in } \\
\text { patients with anemia }\end{array}$ & $\begin{array}{l}\text { Moderate } \\
\text { (should not } \\
\text { require } \\
\text { transfusion) }\end{array}$ \\
\hline $\begin{array}{l}\text { Acute aseptic meningitis } \\
\text { within } 48-72 \mathrm{~h} \text { after } \\
\text { infusion }\end{array}$ & $<0.1$ & $\begin{array}{l}\text { - Fast infusion rate } \\
\text { - History of migraine }\end{array}$ & $\begin{array}{l}\text { - Release of inflammatory } \\
\text { cytokines } \\
\text { - Presence of ANCA-like } \\
\text { immunoglobulins }\end{array}$ & $\begin{array}{l}\text { - Anti-inflammatory agents } \\
\text { and pain killers }\end{array}$ & $\begin{array}{l}\text { Moderate } \\
\text { and } \\
\text { transient }\end{array}$ \\
\hline $\begin{array}{l}\text { Arterial or venous } \\
\text { thromboembolic event } \\
\text { (transient ischemic attack, } \\
\text { stroke or peripheral deep } \\
\text { thromboembolism) } \\
\text { starting within } 24 \mathrm{~h} \text { after } \\
\text { infusion }\end{array}$ & $<0.1$ & $\begin{array}{l}\text { - First infusion of IVIg } \\
\text { - Age > } 60 \mathrm{yr} \\
\text { - High dose } \\
\text { - Previous thrombotic event } \\
\text { and thrombophilia } \\
\text { - Risk factors for cardiovascular } \\
\text { events (e.g., dyslipidemia, } \\
\text { hypertension, diabetes) } \\
\text { - Autoimmune disease or } \\
\text { cancer }\end{array}$ & $\begin{array}{l}\text { - Rheological properties of IVIg } \\
\text { leading to hyperviscosity } \\
\text { - Contamination with clotting } \\
\text { factors } \\
\text { - Vasospasm secondary to } \\
\text { release of vasoactive } \\
\text { molecules } \\
\text { - Formation of platelet- } \\
\text { leukocyte aggregates }\end{array}$ & $\begin{array}{l}\text { - Prophylactic hydration } \\
\text { - Slow infusion of IVlg } \\
\text { - Early treatment of high-risk } \\
\text { patients } \\
\text { - Prophylactic anticoagulation }\end{array}$ & $\begin{array}{l}\text { Moderate } \\
\text { to severe }\end{array}$ \\
\hline $\begin{array}{l}\text { Hypertension and fluid } \\
\text { overload during infusion } \\
\text { and lasting up to } 2 \mathrm{~d} \\
\text { after infusion }\end{array}$ & $<1$ & $\begin{array}{l}\text { - Previous elevated plasma } \\
\text { viscosity (e.g., polycythemia, } \\
\text { paraproteinemia) } \\
\text { - Previous heart and kidney } \\
\text { failure }\end{array}$ & $\begin{array}{l}\text { - Hypergammaglobulinemia } \\
\text { and viscosity }\end{array}$ & - Adequate hydration & $\begin{array}{l}\text { Moderate } \\
\text { to severe }\end{array}$ \\
\hline $\begin{array}{l}\text { Acute renal failure (from } \\
\text { transient mild alteration } \\
\text { in renal function to renal } \\
\text { failure requiring dialysis) } \\
\text { starting within 1-10 d } \\
\text { after infusion }\end{array}$ & $<1$ & $\begin{array}{l}\text { - Age > } 60 \text { yr } \\
\text { - Obesity and type } 1 \text { diabetes } \\
\text { - Pre-existing renal disease } \\
\text { - Sepsis } \\
\text { - Paraproteinemia } \\
\text { - Use of nephrotoxic agents }\end{array}$ & $\begin{array}{l}\text { - Direct toxicity on proximal } \\
\text { renal tubular epithelial cells, } \\
\text { osmotic tubular injury } \\
\text { secondary to stabilizers used } \\
\text { in IVIg preparation (sucrose, } \\
\text { maltose, glucose) } \\
\text { - Cryoglobulin precipitate }\end{array}$ & $\begin{array}{l}\text { - Adequate hydration } \\
\text { - Monitoring of renal function } \\
\text { before and after infusion } \\
\text { - Use of sugar-free stabilizers } \\
\text { - Avoidance of concomitant } \\
\text { nephrotoxic therapy } \\
\text { - Avoidance in cryoglobulinic- } \\
\text { positive patients }\end{array}$ & $\begin{array}{l}\text { Mild to } \\
\text { severe }\end{array}$ \\
\hline $\begin{array}{l}\text { Non-IgE-mediated } \\
\text { anaphylactic reaction } \\
\text { (from tightness of throat } \\
\text { or chest, chills and rigor to } \\
\text { breathlessness, dizziness, } \\
\text { fainting or collapse and } \\
\text { death) starting early } \\
\text { during infusion }\end{array}$ & $<0.1$ & $\begin{array}{l}\text { - IgA deficiency ( } 20 \% \text { related } \\
\text { to anti-lgA antibodies, } \\
\text { particularly in patients with } \\
\text { systemic lupus erythematosus } \\
\text { or myasthenia) }\end{array}$ & $\begin{array}{l}\text { - Anti-IgA antibodies (IgG } \\
\text { isotypes) reacting with IgA in } \\
\text { IVIg preparations }\end{array}$ & $\begin{array}{l}\text { - Discontinuation of infusion } \\
\text { and supportive treatment } \\
\text { (intensive care unit) } \\
\text { - Screening of IgA deficiency } \\
\text { in patients before infusion } \\
\text { - Use of IVIg preparation with } \\
\text { lower concentration of IgA }\end{array}$ & $\begin{array}{l}\text { Moderate } \\
\text { to severe }\end{array}$ \\
\hline $\begin{array}{l}\text { Local reaction to } \\
\text { subcutaneous } \\
\text { immunoglobulin (swelling, } \\
\text { redness, itching or burning } \\
\text { sensation) }\end{array}$ & $8-50$ & $\begin{array}{l}\text { - Initiation of subcutaneous } \\
\text { therapy }\end{array}$ & - Local irritant effect & $\begin{array}{l}\text { - Symptomatic management } \\
\text { - Monitoring to ensure no } \\
\text { long-term changes such as } \\
\text { fat necrosis or fibrosis }\end{array}$ & $\begin{array}{l}\text { Mild to } \\
\text { moderate }\end{array}$ \\
\hline
\end{tabular}


that predict treatment success, even in situations for which a well-documented evidence base exists. Treatment-responsive subsets of diseases have to be identified to clarify the real impact of immunoglobulin therapy. Furthermore, one could expect differences in effectiveness between the various preparations because of their different subclass compositions, but data are lacking as to whether this has important clinical implications.

In several diseases, the effect of intravenous immunoglobulin is transient. In the event of relapses, long-term management is difficult because optimal combination therapy or schedules of treatment are not well established.

Because of safety issues and manufacturing processes, the cost of intravenous immunoglobulin is not likely to decrease. Thus, use of more concentrated preparations may be an alternative to reduce the duration of infusion and the time required for involvement of health professionals. Subcutaneous administration of immunoglobulin has shown promising results in patients with multifocal motor neuropathy, ${ }^{49}$ and other trials of subcutaneous use are under way in patients with myasthenia gravis (ClinicalTrials.gov NCT01828294), chronic inflammatory demyelinating polyneuropathy (ClinicalTrials.gov NCT01017159) and dermatomyositis (ClinicalTrials.gov NCT02271165).

Another concern relates to the limited availability of immunoglobulin, because shortages have occurred in the past. In such circumstances, priority for allocation should be given to indications for which strong evidence of benefit exists or to severe life-threatening conditions. Alternatively, in view of promising results in experimental models, ${ }^{50}$ clinical trials should be undertaken with recombinant sialylated Fc fragments of $\mathrm{IgG}$ that are not derived from blood, which could help to overcome shortages of intravenous immunoglobulin in the future.

\section{References}

1. Kazatchkine MD, Kaveri SV. Immunomodulation of autoimmune and inflammatory diseases with intravenous immune globulin. N Engl J Med 2001;345:747-55.

2. Fehr J, Hofmann V, Kappeler U. Transient reversal of thrombocytopenia in idiopathic thrombocytopenic purpura by high-dose intravenous gamma globulin. N Engl J Med 1982;306:1254-8.

3. Samuelsson A, Towers TL, Ravetch JV. Anti-inflammatory activity of IVIG mediated through the inhibitory Fc receptor. Science 2001;291:484-6.

4. Basta M, Van Goor F, Luccioli S, et al. F(ab)'2-mediated neutralization of C3a and C5a anaphylatoxins: a novel effector function of immunoglobulins. Nat Med 2003;9:431-8.

5. Gelfand EW. Intravenous immune globulin in autoimmune and inflammatory diseases. N Engl J Med 2012;367:2015-25.

6. Bayry J, Mouthon L, Kaveri SV. Intravenous immunoglobulin expands regulatory $\mathrm{T}$ cells in autoimmune rheumatic disease. J Rheumatol 2012;39:450-1.

7. Maddur MS, Vani J, Hegde P, et al. Inhibition of differentiation, amplification, and function of human TH17 cells by intravenous immunoglobulin. J Allergy Clin Immunol 2011;127:823-30.e1-7.

8. Le Pottier L, Sapir T, Bendaoud B, et al. Intravenous immunoglobulin and cytokines: focus on tumor necrosis factor family members BAFF and APRIL. Ann N Y Acad Sci 2007;1110:426-32.
9. Elovaara I, Apostolski S, van Doorn P, et al. EFNS guidelines for the use of intravenous immunoglobulin in treatment of neurological diseases: EFNS task force on the use of intravenous immunoglobulin in treatment of neurological diseases. Eur J Neurol 2008; 15:893-908

10. Patwa HS, Chaudhry V, Katzberg H, et al. Evidence-based guideline: intravenous immunoglobulin in the treatment of neuromuscular disorders: report of the Therapeutics and Technology Assessment Subcommittee of the American Academy of Neurology. Neurology 2012;78:1009-15.

11. Eftimov F, Winer JB, Vermeulen M, et al. Intravenous immunoglobulin for chronic inflammatory demyelinating polyradiculoneuropathy. Cochrane Database Syst Rev 2009;(1):CD001797.

12. Nobile-Orazio E, Cocito D, Jann S, et al. Intravenous immunoglobulin versus intravenous methylprednisolone for chronic inflammatory demyelinating polyradiculoneuropathy: a randomised controlled trial. Lancet Neurol 2012;11:493-502.

13. Hughes RAC, Swan AV, van Doorn PA. Intravenous immunoglobulin for Guillain-Barré syndrome. Cochrane Database Syst Rev 2012; 7:CD002063.

14. Gajdos P, Chevret S, Toyka KV. Intravenous immunoglobulin for myasthenia gravis. Cochrane Database Syst Rev 2012;12: CD002277.

15. Barth D, Nabavi Nouri M, Ng E, et al. Comparison of IVIg and PLEX in patients with myasthenia gravis. Neurology 2011;76: 2017-23.

16. Gajdos P, Tranchant C, Clair B, et al.; Myasthenia Gravis Clinical Study Group. Treatment of myasthenia gravis exacerbation with intravenous immunoglobulin: a randomized double-blind clinical trial. Arch Neurol 2005;62:1689-93.

17. van Schaik IN, van den Berg LH, de Haan R, et al. Intravenous immunoglobulin for multifocal motor neuropathy. Cochrane Database Syst Rev 2005;(2):CD004429.

18. Czernik A, Toosi S, Bystryn JC, et al. Intravenous immunoglobulin in the treatment of autoimmune bullous dermatoses: an update. Autoimmunity 2012;45:111-8.

19. Amagai M, Ikeda S, Shimizu H, et al. A randomized double-blind trial of intravenous immunoglobulin for pemphigus. J Am Acad Dermatol 2009;60:595-603.

20. Jolles S. A review of high-dose intravenous immunoglobulin (hdIVIg) in the treatment of the autoimmune blistering disorders. Clin Exp Dermatol 2001;26:127-31.

21. Gaitanis G, Alexis I, Pelidou S-H, et al. High-dose intravenous immunoglobulin in the treatment of adult patients with bullous pemphigoid. Eur J Dermatol 2012;22:363-9.

22. Murrell DF, Daniel BS, Joly P, et al. Definitions and outcome measures for bullous pemphigoid: recommendations by an international panel of experts. J Am Acad Dermatol 2012;66:479-85.

23. Imbach $\mathrm{P}$, Wagner HP, Berchtold $\mathrm{W}$, et al. Intravenous immunoglobulin versus oral corticosteroids in acute immune thrombocytopenic purpura in childhood. Lancet 1985;2:464-8.

24. Qin YH, Zhou TB, Su LN, et al. The efficacy of different dose intravenous immunoglobulin in treating acute idiopathic thrombocytopenic purpura: a meta-analysis of 13 randomized controlled trials. Blood Coagul Fibrinolysis 2010;21:713-21.

25. Godeau B, Lesage S, Divine M, et al. Treatment of adult chronic autoimmune thrombocytopenic purpura with repeated high-dose intravenous immunoglobulin. Blood 1993;82:1415-21.

26. Oates-Whitehead RM, Baumer JH, Haines L, et al. Intravenous immunoglobulin for the treatment of Kawasaki disease in children. Cochrane Database Syst Rev 2003;(4):CD004000.

27. Furusho K, Kamiya T, Nakano H, et al. High-dose intravenous gammaglobulin for Kawasaki disease. Lancet 1984;2:1055-8.

28. Chen S, Dong Y, Yin Y, et al. Intravenous immunoglobulin plus corticosteroid to prevent coronary artery abnormalities in Kawasaki disease: a meta-analysis. Heart 2013;99:76-82.

29. Jordan SC, Tyan D, Stablein D, et al. Evaluation of intravenous immunoglobulin as an agent to lower allosensitization and improve transplantation in highly sensitized adult patients with end-stage renal disease: report of the NIH IG02 trial. J Am Soc Nephrol 2004;15:3256-62.

30. Casadei DH, del C Rial M, Opelz G, et al. A randomized and prospective study comparing treatment with high-dose intravenous immunoglobulin with monoclonal antibodies for rescue of kidney grafts with steroid-resistant rejection. Transplantation 2001;71:53-8

31. Gordon PA, Winer JB, Hoogendijk JE, et al. Immunosuppressant and immunomodulatory treatment for dermatomyositis and polymyositis. Cochrane Database Syst Rev 2012;8:CD003643.

32. Dalakas MC. Controlled studies with high-dose intravenous immunoglobulin in the treatment of dermatomyositis, inclusion body myositis, and polymyositis. Neurology 1998;51(Suppl 5):S37-45.

33. Cherin P, Pelletier S, Teixeira A, et al. Results and long-term followup of intravenous immunoglobulin infusions in chronic, 
refractory polymyositis: an open study with thirty-five adult patients. Arthritis Rheum 2002;46:467-74.

34. Cherin P, Piette JC, Wechsler B, et al. Intravenous gamma globulin as first line therapy in polymyositis and dermatomyositis: an open study in 11 adult patients. J Rheumatol 1994;21:1092-7.

35. Bayry J, Negi VS, Kaveri SV. Intravenous immunoglobulin therapy in rheumatic diseases. Nat Rev Rheumatol 2011;7:349-59.

36. Provan D, Chapel HM, Sewell WAC, et al. Prescribing intravenous immunoglobulin: summary of Department of Health guidelines. BMJ 2008;337:a1831.

37. Fazekas F, Deisenhammer F, Strasser-Fuchs S, et al. Randomised placebo-controlled trial of monthly intravenous immunoglobulin therapy in relapsing-remitting multiple sclerosis. Austrian Immunoglobulin in Multiple Sclerosis Study Group. Lancet 1997;349:589-93

38. Pöhlau D, Przuntek H, Sailer M, et al. Intravenous immunoglobulin in primary and secondary chronic progressive multiple sclerosis: a randomized placebo controlled multicentre study. Mult Scler 2007;13:1107-17.

39. Relkin N; ADCS and Baxter GAP 160701 study group. Results of the GAP 160701 study: a phase 3 clinical trial of intravenous immunoglobulin for mild-to-moderate Alzheimer's disease. Alzheimers Dement 2013;9(4 Suppl):P530.

40. Silverman ED, Cawkwell GD, Lovell DJ, et al. Intravenous immunoglobulin in the treatment of systemic juvenile rheumatoid arthritis: a randomized placebo controlled trial. Pediatric Rheumatology Collaborative Study Group. J Rheumato 1994;21:2353-8.

41. Dalakas MC, Sonies B, Dambrosia J, et al. Treatment of inclusion-body myositis with IVIg: a double-blind, placebo-controlled study. Neurology 1997;48:712-6.

42. Paul C, Lahfa M, Bachelez $\mathrm{H}$, et al. A randomized controlled evaluator-blinded trial of intravenous immunoglobulin in adults with severe atopic dermatitis. Br J Dermatol 2002;147:518-22.

43. Bux J, Behrens G, Jaeger G, et al. Diagnosis and clinical course of autoimmune neutropenia in infancy: analysis of 240 cases. Blood 1998;91:181-6.

44. Joly P, Janela B, Tetart F, et al. Poor benefit/risk balance of intravenous immunoglobulins in DRESS. Arch Dermatol 2012; 148:543-4.

45. Emmenegger U, Frey U, Reimers A, et al. Hyperferritinemia as indicator for intravenous immunoglobulin treatment in reactive macrophage activation syndromes. Am J Hematol 2001;68:4-10.

46. Imashuku S, Kuriyama K, Teramura T, et al. Requirement for etoposide in the treatment of Epstein-Barr virus-associated hemophagocytic lymphohistiocytosis. J Clin Oncol 2001;19:2665-73.

47. Caress JB, Kennedy BL, Eickman KD. Safety of intravenous immunoglobulin treatment. Expert Opin Drug Saf 2010;9:971-9.

48. Hooper JA. Intravenous immunoglobulins: evolution of commercial IVIG preparations. Immunol Allergy Clin North Am 2008;28:765-78.

49. Harbo T, Andersen H, Hess A, et al. Subcutaneous versus intravenous immunoglobulin in multifocal motor neuropathy: a randomized, single-blinded cross-over trial. Eur J Neurol 2009;16:631-8.

50. Kaneko Y, Nimmerjahn F, Ravetch JV. Anti-inflammatory activity of immunoglobulin $\mathrm{G}$ resulting from $\mathrm{Fc}$ sialylation. Science 2006;313:670-3.

Affiliations: Unité 872, Institut national de la santé et de la recherche médicale, and Équipe 16: Immunopathologie et immuno-intervention thérapeutique, Centre de recherche des Cordeliers, Université Pierre et Marie Curie and Université Paris Descartes, Paris, France

Contributors: Laurent Gilardin performed the literature search. All of the authors reviewed the literature, drafted and revised the manuscript, approved the final version for publication and agreed to act as guarantors of the work.

Acknowledgements: The authors thank Olivier Benveniste for critical reading of the manuscript, Antoine Guéguen and Denis Glotz for their constructive comments and Mathieu Ing for his help in drawing the figure. Laurent Gilardin was the recipient of a Poste d'accueil INSERM, Institut national de la santé et de la recherche médicale.

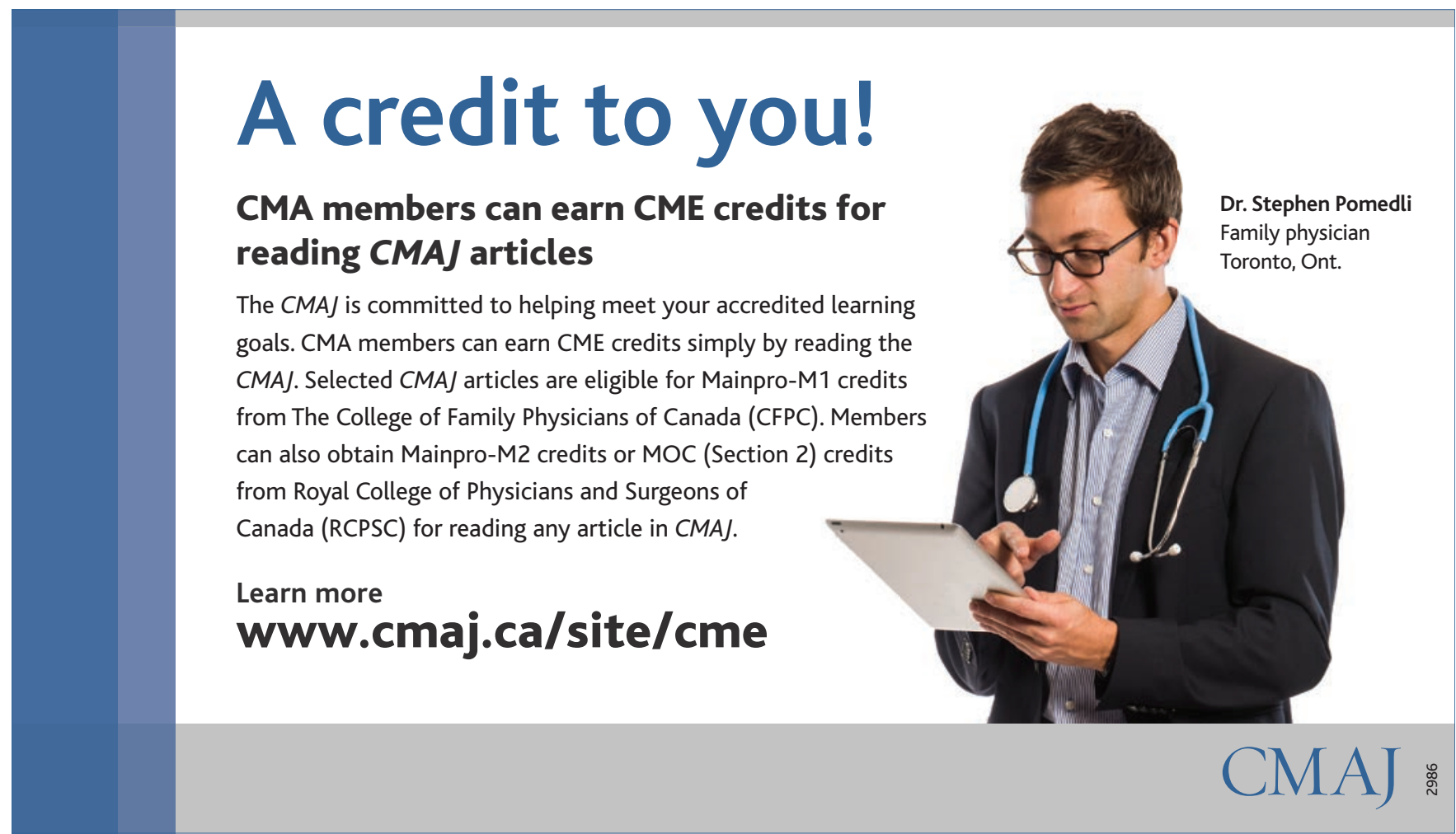

